\title{
STRATEGI KOMUNIKASI KOMINFO DALAM MENGHADAPI FENOMENA PENYEBARAN UJARAN KEBENCIAN
}

\author{
Ekky Dwi Pratama, Aprida Sihombing \\ Sekolah Tinggi Ilmu Komunikasi London School of Public Relations Jakarta \\ ekky.dwipratama@gmail.com,Aprida.ms@lspr.edu
}

\begin{abstract}
ABSTRAK
Fenomena Ujaran Kebencian (Hate Speech) saat ini memiliki potensi untuk muncul kembali pada kontestasi politik yaitu pilkada serentak 2018 serta pilpres 2019 dan memiiki dampak yang sangat membahayakan bagi kesatuan dan persatuan bangsa Indonesia apabila politik SARA (Suku, Agama, Ras, dan Antar Golongan) dan ujaran kebencian ini digunakan untuk memenangkan suatu kekuasaan. Oleh karena itu, pemerintah harus segera melakukan tindakan pencegahan untuk menghadapi potensi timbulnya fenomena ini, dalam hal ini Kemenkominfo (Kementerian Komunikasi dan Informatika) membuat suatu strategi komunikasi yang di dalamnya terdapat program literasi kepada masyarakat sebagai suatu langkah pencegahan yang dilakukan oleh pemerintah untuk menghadapi fenomena ini. Pendekatan penelitian kualitatif dengan wawancara pada staf di Kemenkominfo dilakukan dalam penelitian ini. Hasil penelitian ini menunjukan strategi komunikasi yang dibuat dan dilakukan oleh Kemenkominfo untuk menghadapi fenomena tersebut yakni dengan pemilihan komunikator, memilih dan menetapkan target sasaran, menyusun dan menyampaikan pesan, serta cermat memilih medianya.
\end{abstract}

Kata Kunci : Strategi komunikasi, Kemenkominfo, ujaran kebencian

\begin{abstract}
The phenomenon of Hate Speech now has the potential to reappear on the election of regional head contestation of the 2018 election as well as 2019 presidential election and have a very harmful impact on the unity of the Indonesian people when the SARA (Ethnic, Religious, Race, and Group) issue used in politics and hate speech are used to win a power. Therefore, the government must immediately take preventive action to face the potential emergence of this phenomenon, in this case Kemenkominfo create a communication strategy in which there is a literacy program to the community as a preventive measure undertaken by the government to face this phenomenon.This research use qualitative approach by interview to Kemenkominfo staffs. Result of this research showed that Kemenkominfo using some strategy of communication as: choose the communicator, choose and define the target, create and distribute message, also carefully choose the media.
\end{abstract}

Keywords : Communication strategy, Kemenkominfo, hate speech 


\section{PENDAHULUAN}

Pada era globalisasi dan modernisasi teknologi saat ini, fenomena media sosial sangat berperan dan berpengaruh dalam aktivitas keseharian bersosial dimasyarakat. Perkembangan teknologi komunikasi saat ini yang sangat pesat memberikan dampak yang signifikan diberbagai bidang seperti sosial, ekonomi, pendidikan, dan bidang bidang yang lainnya.

Pada zaman globalisasi saat ini bisa dikatakan bahwa "new media" menjadi media yang paling banyak digunakan oleh mayoritas masyarakat untuk mendapatkan berbagai informasi. Fenomena media online dan media sosial pada era saat ini merupakan bagian dari evolusi penggunaan teknologi informasi. Secara prinsip, teknologi itu bebas nilai, sehingga teknologi bisa dipakai baik untuk hal yang positif maupun negatif, dilihat dari kacamata moral, etika, agama. Melihat fenomena penggunaan media online dan media sosial pada era saat ini dibuktikan dengan semakin meningkatnya populasi pengguna internet di seluruh dunia tidak terkecuali di negara Indonesia.

"Data dari lembaga riset pasar e-Marketer mengatakan bahwa populasi netter Indonesia mencapai 83,7 juta pada tahun 2014 dan pada tahun 2017 e-Marketer memperkirakan netter Indonesia akan mencapai 112 juta orang mengalahkan Jepang diperingkat ke-5 yang pertumbuhan jumlah pengguna internetnya lebih lamban" Dikutip dari tekno.kompas.com (Oik Yusuf,24 November 2014).

\section{Gambar 1.}

Jumlah dan proyeksi jumlah pengguna internet di dunia dari

\begin{tabular}{|c|c|c|c|c|c|c|}
\hline & 2013 & 2014 & 2015 & 2016 & 2017 & 2018 \\
\hline 1. China* & 620.7 & 643.6 & 669.8 & 700.1 & 736.2 & 777.0 \\
\hline 2. US" & 246.0 & 252.9 & 259.3 & 264.9 & 269.7 & 274.1 \\
\hline 3. India & 167.2 & 215.6 & 252.3 & 283.8 & 313.8 & 346.3 \\
\hline 4. Brazil & 99.2 & 107.7 & 113.7 & 119.8 & 123.3 & 125.9 \\
\hline 5. Japan & 100.0 & 102.1 & 103.6 & 104.5 & 105.0 & 105.4 \\
\hline 6. Indonesia & 72.8 & 83.7 & 93.4 & 102.8 & 112.6 & 123.0 \\
\hline 7. Russia & 77.5 & 829 & 873 & 91.4 & 94.3 & 96.6 \\
\hline 8. Germany & 59.5 & 61.6 & 62.2 & 62.5 & 62.7 & 62.7 \\
\hline 9. Mexico & 53.1 & 59.4 & 65.1 & 70.7 & 75.7 & 80.4 \\
\hline 10. Nigeria & 51.8 & 57.7 & 63.2 & 69.1 & 76.2 & 84.3 \\
\hline 11. UK* & 48.8 & 50.1 & 51.3 & 52.4 & 53.4 & 54.3 \\
\hline 12. France & 48.8 & 49.7 & 50.5 & 51.2 & 51.9 & 52.5 \\
\hline 13. Philippines & 42.3 & 48.0 & 53.7 & 59.1 & 64.5 & 69.3 \\
\hline
\end{tabular}

\begin{tabular}{|c|c|c|c|c|c|c|}
\hline 14. Turkey & 36.6 & 41.0 & 44.7 & 47.7 & 50.7 & 53.5 \\
\hline 15. Vietnam & 36.6 & 40.5 & 44.4 & 48.2 & 52.1 & 55.8 \\
\hline 16. South Korea & 40.1 & 40.4 & 40.6 & 40.7 & 40.9 & 41.0 \\
\hline 17. Egypt & 34.1 & 36.0 & 38.3 & 40.9 & 43.9 & 47.4 \\
\hline 18. Italy & 34.5 & 35.8 & 36.2 & 37.2 & 37.5 & 37.7 \\
\hline 19. Spain & 30.5 & 31.6 & 32.3 & 33.0 & 33.5 & 33.9 \\
\hline 20. Canada & 27.7 & 28.3 & 28.8 & 29.4 & 29.9 & 30.4 \\
\hline 21. Argentina & 25.0 & 27.1 & 29.0 & 29.8 & 30.5 & 31.1 \\
\hline 22. Colombia & 24.2 & 26.5 & 28.6 & 29.4 & 30.5 & 31.3 \\
\hline 23. Thailand & 22.7 & 24.3 & 26.0 & 27.6 & 29.1 & 30.6 \\
\hline 24. Poland & 22.6 & 22.9 & 23.3 & 23.7 & 24.0 & 24.3 \\
\hline 25. South Africa & 20,1 & 22.7 & 25.0 & 27.2 & 29.2 & 30.9 \\
\hline Worldwide*t. & $2,692.9$ & $2,892.7$ & $3,072.6$ & 3.246 .3 & 3.419 .9 & $3,600.2$ \\
\hline \multicolumn{7}{|c|}{$\begin{array}{l}\text { Note: individuals of any age who use the internet from any location via any } \\
\text { device at least once per month" "excludes Hong Kong: " forecast from Aug } \\
2014 ; \text {; includes countries not listed } \\
\text { Source: eMarketer, Nov } 2014\end{array}$} \\
\hline
\end{tabular}

Sumber : www.emarketer.com,2014

Dari data tersebut dapat dikatakan bahwa Indonesia menjadi salah satu negara yang menyumbangkan pengguna internet terbanyak di dunia dengan jumlah pengguna yang 
terus meningkat setiap tahunnya. Oleh karena itu di Indonesia pada era saat ini penggunaan new media atau media online sangat banyak digunakan dan dimanfaatkan untuk menyebarkan berbagai informasi dan terlebih lagi saat ini media online menjadi wadah untuk berdiskusi dan bertukar informasi bahkan dimanfaatkan sebagai lahan bisnis bagi para pebisnis.

Media online atau "new media" sebenarnya memiliki dampak yang baik dan positif bagi masyarakat untuk dapat memperoleh serta menyebarkan berbagai informasi secara cepat,aktual dan faktual melalui media online, namun di sisi lain media online ini memiliki dampak yang negatif pula bagi masyarakat apabila masyarakat tidak baik dan bijak dalam memanfaatkan kemudahan yang didapatkan melalui penggunaan media online. salah satu problem besar yang dihadapi media online sekaligus menjadi dampak negatif dari media tersebut pada saat ini ialah banyaknya informasi dan berita yang tidak benar atau bohong (hoax), lalu provokatif yang biasanya cenderung memfitnah serta menjatuhkan pihak tertentu yang biasanya disampaikan melalui suatu ujaran atau statement yang mengandung rasa kebencian (hate speech) yang tentunya akan berpengaruh langsung pada persepsi para pengguna media online terhadap berita dan informasi yang disebarkan serta menggiring opini negatif publik terhadap pihak tertentu. Fenomena ujaran kebencian (hate speech) sekarang ini banyak tersebar di berbagai media terutama media online pada saat ini. Masyarakat Indonesia pada umumnya sangat sensitif jika ada hal yang berkaitan dengan ujaran kebencian yang keberadaannya meresahkan masyarakat akhir-akhir ini, karena bisa berdampak pada semakin banyaknya konflik yang terjadi dan menjadi sangat rawan bagi keutuhan dan kesatuan bangsa Indonesia. Penyeberan ujaran kebencian ini dapat dengan mudah langsung mempengaruhi pikiran dan persepsi masyarakat tentang suatu suku,agama,ras,dan golongan yang pada akhirnya mendorong peluang terjadinya konflik menjadi semakin besar baik secara vertikal maupun horizontal di lingkungan masyarakat dengan adanya hate speech atau ujaran kebencian tersebut. Banyak kasus dan peristiwa penyebaran hate speech ini yang sebenarnya tidak sesuai dengan fakta atau realita yang terjadi namun hal tersebut disebarkan secara masif menjadi sebuah informasi yang dikemas sedemikian rupa agar para pembaca atau khalayak tertarik dan terpengaruh oleh berita atau informasi tersebut.

Dikutip dari kominfo.go.id "Kementerian Komunikasi dan Informatika (Kemenkominfo) selama periode 1 Januari hingga akhir Juli 2017 telah menerima email pengaduan konten negatif. Kategori SARA atau Kebencian, pornografi, dan Hoax menempati tiga urutan tertinggi pengaduan konten negatif. Konten SARA mencapai puncak tertinggi pada Januari 2017 dengan 5.142 aduan.Sementara itu, media sosial yang berbau pornografi berjumlah 9.000 lebih dan konten hoax sekitar 6.632."(Nur Islami, 16 Agustus 2017)

"Berdasarkan data Kementerian Komunikasi dan Informatika, sepanjang tahun 2017 tercatat ada 13.829 konten negatif berupa ujaran kebencian yang marak di media sosial, 6.973 berita bohong dan 13.120 konten pornografi." (Ayu Yuliani, 12 Desember 2017) 
Dari data-data di atas dapat dikatakan bahwa potensi berkembangnya berita-berita dan informasi yang mengandung hate speech atau ujaran kebencian sangatlah besar terutama dengan menggunakan media online yang saat ini sangat mudah untuk digunakan oleh pembuat berita dan diakses oleh pengguna internet, terlebih masih banyaknya portal berita, serta situs-situs yang belum terverifikasi yang mempunyai potensi besar untuk menyebarkan informasi dan berita-berita yang mengandung unsur ujaran kebencian.

Terlebih pada tahun 2018 mendatang akan ada pilkada serentak untuk kedua kalinya dan di 2019 akan ada pilpres dan pileg serentak yang tentunya akan menjadi kesempatan dan peluang yang sangat besar bagi para pelaku tersebut untuk memperoleh keuntungan dari penyeberan konten berita yang mengandung hate speech. Apabila hal seperti ini tidak bisa dihentikan mata rantainya maka akan sangat berdampak pada keutuhan dan kemajemukan masyarakat Indonesia sehingga akan bermunculan sentimen rasial dan diskriminatif.

Kurangnya literasi media yang dilakukan oleh pemerintah terhadap masyarakat menjadi salah satu faktor mengapa masyarakat Indonesia dapat dengan mudah terpengaruh, terpancing dan percaya terhadap hal-hal yang belum tentu kebenarannya. Masih banyak bagian dari masyarakat kita yang malas untuk melakukan check, rechek dan crosscheck, atau klarifikasi ketika mendapat informasi. Masyarakat kita pun masih sangat mudah terprovokasi dan percaya pada isu yang didapatkan.

Oleh karena itu pemerintah harus mengambil peran dan tugasnya dalam meyikapi serta menghadapi fenomena ini. Upaya meningkatkan literasi media kepada masyarakat merupakan tugas dan tanggung jawab pemerintah dan merupakan hak rakyat untuk menerima program-program literasi media agar dapat menangkal hal-hal negatif dari semakin canggihnya media saat ini. Berangkat dari fenomena tersebut peneliti tertarik untuk meneliti mengenai bagaimana peran pemerintah dalam menghadapi fenomena penyebaran ujaran kebencian (hate speech) Oleh karena itu peneliti mengangkat judul penelitian yaitu: "Strategi Komunikasi KOMINFO dalam Menghadapi Fenomena Penyebaran Ujaran Kebencian"

\section{TINJAUAN PUSTAKA}

\section{Teori dalam Strategi Komunikasi}

Dari sekian banyak teori komunikasi yang dikemukakan oleh para ahli, untuk strategi komunikasi yang memadai adalah teori dari seorang ilmuan politik dari Amerika Serikat yang bernama Harold D. Lasswell yang menyatakan bahwa cara yang terbaik untuk menerangkan kegiatan komunikasi atau cara untuk menggambarkan dengan tepat sebuah tindak komunikasi ialah menjawab pertanyaan "Who Says What In Which Channel To Whom With What Effect? (siapa mengatakan apa dengan cara apa kepada siapa dengan efek bagaimana)". 
Gambar 2.

Laswell Model of Communication

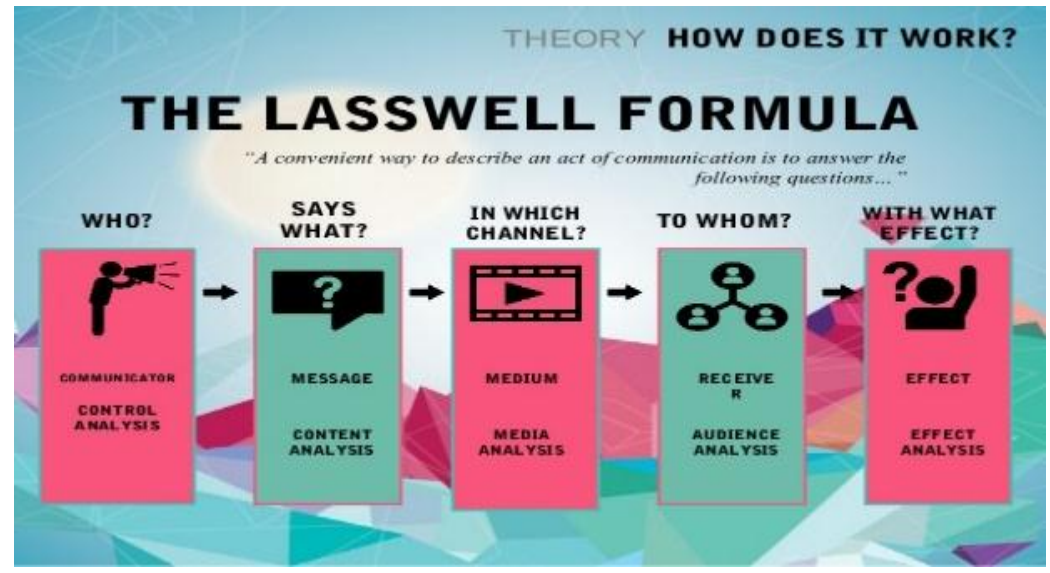

Sumber: slideshare.com, 1948

Formula dari Lasswell tersebut termasuk dalam kategori model-model dasar dalam stretegi komunikasi. Formula sederhana ini telah digunakan dengan berbagai cara, terutama untuk mengatur dan mengorganisasikan dan membentuk struktur tentang proses komunikasi. Formula Laswell menunjukkan kecenderungan-kecenderungan awal model-model komunikasi, yaitu menganggap bahwa komunikator pasti mempunyai "receiver" (penerima) dan karenanya komunikasi harus semata-mata dianggap sebagai proses persuasif. Juga selalu dianggap bahwa pesan-pesan itu akan selalu memiliki efek.

\section{Memilih dan Menetapkan Komunikator}

Komunikator menjadi sumber dan kendali sama aktivitas komunikasi karena itu jika suatu proses komunikasi tidak berhasil dengan baik, maka kesalahan utama bersumber dari komunikator, karena komunikatorlah yang tidak memahami penyusunan pesan, memilih media yang tepat dan mendekati khalayak yang menjadi target sasaran (Cangara,2014, p.133-146)

3 syarat seorang komunikator :

1. Kepercayaan (credibilitas)

2. Daya tarik (attractive)

3. Kekuatan (power)

\section{Mengenal Khalayak dan Sasaran}

Mengenali khalayak dan sasaran merupakan hal yang wajib dilakukan untuk mempermudah dalam pemilihan komunikator, sesuai dengan situasi dan kondisi yang ada. Memahami masyarakat,terutama yang akan menjadi target sasaran program komunikasi merupakan hal yang sangat penting. Sebab semua aktivitas komunikasi diarahkan kepada mereka. Merekalah yang menentukan berhasil dan tidaknya suatu program komunikasi yang dilakukan. Untuk mengetahui dan memahami segmentasi masyarakat. Ada tiga cara yang bisa digunakan untuk memetakan karakteristik masyarakat yakni : 
a. Aspek sosiodemografik, mencakup usia, jenis kelamin, pekerjaan, pendidikan, tingkat pendapatan, agama, ideology, etnis, termasuk kepemilikan media.

b. Aspek psikologis, mencakup sikap yang tercermin dari kejiwaan masyarakat, misalnya tempramen, tenang, sabar, terbuka, emosional, tertutup, berani, penakut.

c. Aspek karakteristik perilaku masyarakat, mencakup kebiasaan yang dijalani dalam kehidupan suatu masyarakat. Misalnya agamais, religius, santun, jujur, tanggung jawab, solidaritas tinggi, dan lain-lain.

\section{Menyusun Pesan}

Wilbur Schramm mengajukan syarat-syarat untuk berhasilnya pesan tersebut (Arifin, 1994, p. 68) sebagai berikut :

a. Pesan harus direncanakan dan disampaikan sedemikian rupa sehingga pesan itu dapat menarik perhatian sasaran yang dituju.

b. Pesan haruslah menggunakan tanda-tanda yang didasarkan pada pengalaman yang sama antara sumber dan sasaran, sehingga kedua pengertian itu bertemu.

c. Pesan harus membangkitkan kebutuhan pribadi daripada sasaran dan menyarankan cara-cara untuk mencapai kebutuhan itu.

d. Pesan harus menyarankan sesuatu jalan untuk memperoleh kebutuhan yang layak bagi situasi kelompok di mana kesadaran pada saat digerakkan untuk memberikan jawaban yang dikehendaki.

Terdapat dua teknik dalam penyusunan pesan :

a. One-side issue, yaitu teknik penyampaian pesan yang menonjolkan sisi kebaikan dan keburukan sesuatu. Artinya seorang komunikator dalam menyampaikan sesuatu harus memberi tekanan apakah pada kebaikannya atau sebaliknya pada keburukannya. Teknik penyampaian ini hanya cocok untuk mereka yang kurang berpendidikan, sehingga tidak mempunyai alternatif pilihan.

b. Two-side issue, yaitu teknik penyampaian pesan dimana komunikator selain mengemukakan yang baik, juga menyampaikan hal-hal yang kurang baik. Komunikator memberi kesempatan kepada khalayak untuk berfikir apakah ada keuntungan jika mereka melaksanakan informasi yang diterimanya.

\section{Menetapkan Teknik}

Dalam komunikasi pada teknik penyampaian atau mempengaruhi itu dapat dilihat dari dua aspek yaitu : menurut cara pelaksanaan dan meurut bentuk isinya. Hal tersebut dapat diuraikan lebih lanjut, bahwa yang pertama, semata-mata melihat komunikasi itu dari segi pelaksanaannya dengan melepaskan perhatian dari isi pesannya. Sedang yang kedua, yaitu melihat komunikasi itu dari segi bentuk pernyataan atau bentuk pesan dan maksud yang dikandung. Oleh karena itu yang pertama menurut cara pelaksanaanya, dapat diwujudkan dalam dua bentuk, yaitu Redundancy (repetition) dan Canalizing. Sedang yang kedua menurut bentuk isinya dikenal teknik-teknik : informatif, persuasif, edukatif, dan koersif (Arifin,1994) 


\section{Penggunaan Medium}

Penggunaan medium sebagai alat penyalur ide, dalam rangka merebut pengaruh khalayak adalah suatu hal yang merupakan keharusan, sebab media dapat menjangkau khalayak yang cukup besar. Media merupakan alat penyalur, juga mempunyai fungsi sosial yang kompleks. Sebagaimana dalam menyusun pesan dari suatu komunikasi yang ingin dilancarkan, kita harus selektif, dalam arti menyesuaikan keadaan dan kondisi khalayak, maka dengan sendirinya dalam penggunaan media pun, harus demikian pula. Justru itu selain kita harus berfikir dalam jalinan faktor-faktor komunikasi sendiri juga harus dalam hubungannya dengan situasi sosial-psikologis, harus diperhitungkan pula. Hal ini karena masing-masing medium tersebut mempunyai kemampuan dan kelemahan-kelemahan tersendiri sebagai alat.

\section{Teori Media Literasi}

The National Leadership Conference on Media Literacy menyatakan bahwa media literacy merupakan kemampuan untuk mengakses, menganalisa, mengevaluasi, dan mengkomunikasikan pesan (Baran, 2004, p.56). Sedangkan Rubin (dalam Baran, 2004, p.56) menyatakan bahwa media literacy adalah pemahaman terhadap sumber-sumber dan teknologi komunikasi, kode-kode yang digunakan, pesan-pesan yang diproduksi, dan seleksi, interpretasi, dan akibat dari pesan-pesan tersebut. Berdasarkan pemaparan di atas, media literasi berarti kemampuan untuk mengakses, menganalisa, mengevaluasi, dan mengkomunikasikan pesan dalam sebuah variasi yang mendalam dengan tidak hanya mempelajari segi-segi produksi, tetapi juga mampu mempelajari kemungkinan apa saja yang bisa muncul akibat kekuatan media Secara ringkas Media Literacy artinya adalah pintar, cakap, mampu dengan baik, menggunakan, memahami, menganalisa, media baik media televisi, radio, surat kabar, dan film.

\section{METODE PENELITIAN}

Sesuai dengan judul penelitian yaitu Strategi Komunikasi Kominfo dalam Menghadapi Fenomena Penyebaran Ujaran Kebencian, peneliti menggunakan pendekatan metode penelitian deskriptif kualitatif. yaitu metode penelitian yang menggambarkan permasalahan yang sedang diteliti serta menjelaskan hal tersebut "mengapa" hal tersebut bisa terjadi dan "bagaimana" cara untuk menyelesaikan permasalahan yang sedang diteliti dengan menggambarkan subyek dan obyek penelitian pada saat ini.

Dengan melakukan metode penelitian deskriptif kualitatif, maka penulis dapat menjabarkan dan menggambarkan kasus yang teliti melalui penafsiran dari jawabanjawaban narasumber. tanpa harus menggunakan metode statistik atau dengan menggunakan metode perhitungan tertentu. Penulis melakukan wawancara dengan narasumber, dan memberikan pertanyaan sesuai dengan topik yang sedang diangkat. Metode penelitian deskriptif kualitatif ini bertujuan untuk mendapatkan data akurat 
yang menjelaskan dan menggambarkan secara rinci mengenai Strategi Komunikasi Kominfo dalam Menghadapi Fenomena Penyebaran Ujaran Kebencian.

\section{Data Primer}

Dalam penelitian ini data primer dilakukan wawancara kepada informan internal diantaranya adalah Ex-Dirjen IKP (Informasi dan Komunikasi Publik) Kominfo RI, Bapak Freddy Tulung, Staff Ahli Bidang Hukum Kominfo, Bapak Henri Subiakto, Staff Ahli Bidang Media dan Komunikasi Massa Kominfo, Bapak Gungun Siswadi, Kepala Subdirektorat Pengolahan dan Penyediaan Informasi Ditjen IKP, Bapak Nursodik Gunarjo.

\section{Teknik Analisis Data}

Analisis data kualitatif dilakukan secara interaktif melalui proses data reduction, data display, serta verification dan berlangsung secara terus menerus pada setiap tahapan penelitian sehingga sampai tuntas, dan datanya jenuh " Mileas and Huberman (Sugiyono, 2012, p.207)

\section{HASIL ANALISIS}

\section{Model Komunikasi Harold Laswell}

Fokus penelitian yang digunakan dalam penelitian ini adalah mengacu pada tahapan komunikasi oleh Harold Laswell yaitu memilih dan menetapkan komunikator (credibility, attractive, power), menetapkan target sasaran (sosiodemografik,psikologis, karakteristik perilaku), teknik menyusun pesan (one side issue, two side issue), Pemilihan media atau saluran komunikasi. Adapun analisis data dari hasil wawancara dapat disimak dalam uraian berikut :

\section{Pemilihan Komunikator}

Pemilihan komunikator yang dilakukan oleh kemenkominfo itu mengacu kepada tiga hal yaitu tupoksi dari pejabat terkait yang memiliki wewenang untuk menyampaikan pesan kepada publik, lalu yang kedua berdasarkan kompetensi, dan yang terakhir harus memiliki kemampuan untuk bermitra dengan media. Hal ini seperti yang dijelaskan oleh staf Ahli bidang Komunikasi dan Media Massa Kemenkominfo yang mengatakan bahwa : "Pemilihan spoke person atau komunikator ini pertama harus sesuai dengan tugas fungsi dan jabatannya, lalu yang yang kedua dilihat dari kompetensinya karena sebagai seorang komunikator atau spoke person dia harus memahami masalahnya apa, menguasai materi atau bahan yang akan disampaikan, serta memiliki pengetahuan mengenai isu-isu yang berkembang saat ini, lalu yang ketiga harus bisa berkolaborasi atau bermitra dengan berbagai macam media baik media konvensional maupun media online dan media sosial karena pada saat sekarang ini kita sangat butuh adanya engagement dengan media sebagai sarana dalam menyampaikan pesan kepada publik atau masyarakat" (Gungun Siswadi, wawancara data primer, 07 Mei 2018) 
Dari tiga acuan tersebut kompetensi merupakan salah satu acuan yang paling penting yang harus dimiliki oleh seorang komunikator atau spoke person. Untuk melihat kompetensi yang dimiliki oleh komunikator ada tiga indikator yang harus dijadikan pertimbangan yaitu credibility (kredibilitas), attractive (daya tarik), power (kekuatan). Kredibilitas (credibility) seorang komunikator dalam menyampaikan pesan di lihat dari bagaimana cara dia dalam mengemas pesan serta bagaimana cara dia mendesiminasikannya kepada publik sesuai dengan target sasaran yang telah ditentukan. seorang spoke person yang memiliki daya tarik (attractive) harus memiliki kemampuan menguasai masalah-masalah atau isu-isu yang sedang berkembang karena orang yang berbicara atau yang bertindak sebagai seorang komunikator jika sudah menguasai masalah yang ada dia akan punya daya tarik tersendiri karena pesan-pesan yang akan disampaikannya juga akan lebih menarik, lalu selain harus menguasai masalah komunikator juga harus memiliki kemampuan untuk memahami karakteristik dari target sasarannya sehingga pendekatan yang digunakan untuk menyampaikan pesannya sesuai dengan karekteristik dari target sasaran sehingga pesan yang disampaikan bisa efektif dan dapat mudah diterima oleh target sasarannya. seorang komunikator yang memiliki power itu harus mempunyai kemampuan atau kekuatan untuk meningkatkan pengetahuan publik, merubah sikap publik dan juga merubah perilaku publik jadi pada intinya seorang komunikator atau spoke person itu harus memiliki kemampuan mempersuasi target sasarannya. Dalam menghadapi fenomena ini kemenkominfo menggunakan komunikator atau spoke person yang kompeten untuk memberikan pemahaman dan mempersuasi publik dengan menggunakan komunikator dari pihakpihak yang terkait dengan fenomena ini seperti pemuka agama, kapolri, menteri hukum dan HAM, serta menteri komunikasi dan informatika. Hal sini seperti yang disampaikan oleh Staf Ahli Kemenkominfo Bidang Hukum: "kami dalam menjalankan literasi ini tidak bergerak sendiri tapi kami disini melibatkan berbagai mitra kami dan pihak-pihak terkait untuk secara bersama-sama melakukan literasi dan edukasi kepada masyarakat untuk menghadapi konten-konten negatif ini salah satunya kan seperti hoax dan SARA ini. Harapannya mitra kami ini bisa menjadi jembatan pemerintah untuk memberikan pemahaman dan edukasi kepada masyarakat terkait dengan isu-isu yang berkembang di masyarakat saat ini"(Henry Subiakto, wawancara data primer, 09 Mei 2018).

\section{Menentukan Target Sasaran}

Langkah yang kedua dalam menyusun suatu strategi komunikasi yaitu memilih dan menetapkan target sasaran. Seperti yang dijelaskan pada langkah awal tadi bahwa pemilihan dan penetapan target sasaran merupakan bagian penting dalam menyusun strategi komunikasi, tujuannya yaitu agar pesan yang akan dirumuskan dan disampaikan kepada publik dapat disesuaikan dengan karakteristik target sasaranya dengan harapan pesan yang disampaikan dapat mudah diterima, dipahami serta dimengerti publik yang pada akhirnya akan mendorong perubahan-perubahan baik sikap dan perilaku dari target sasaran itu sendiri. pemerintah dalam hal ini Kemenkominfo melakukan pemilihan dan penetapan target sasaran dengan cara menyesuaikan serta melihat konteks isu, kasus, atau masalah apa yang sedang dihadapi saat ini. Dalam menghadapi fenomena 
penyebaran ujaran kebencian ini pihak pemerintah perlu melihat pihak-pihak mana saja yang memiliki keterkaitan dan terkena dampak terhadap munculnya fenomena tersebut.

Saat ini dalam menghadapi fenomena penyebaran ujaran kebencian tersebut kominfo menargetkan seluruh masyarakat Indonesia termasuk pihak-pihak yang bermitra dengan pemerintah seperti tokoh-tokoh masyarakat, pemuka-pemuka agama, generasi muda atau biasa disebut generasi millineal untuk mencoba menetralisir penyebaran ujaran kebencian ini. Pada intinya target sasaran pemerintah dalam menghadapi penyebaran ujaran kebencian ini yaitu seluruh masyarakat Indonesia dengan cara pemerintah mencoba untuk memberdayakan seluruh elemen masyarakat untuk bermitra dengan pemerintah dalam memberantas penyebaran isu-isu tersebut. Hal ini sejalan yang dikemukakan oleh Staf Ahli Kominfo di Bidang Hukum; "Lalu yang kedua kalau kita melakukan literasi itu jumlah orang yang harus diberikan literasi itu banyak sekali dan itu menyebabkan kurang efektif sehingga membutuhkan jajaran lain baik itu misalkan pemda-pemda namun sayangnya tidak semua pemda aware atau concern sama isu-isu tersebut dan kurangnya tenaga-tenaga pemda yang tidak memiliki kompetensi tersebut. seakan-akan yang mempunyai satu-satunya tugas tersebut adalah kementerian bersama stakeholders seperti LSM dan lain sebagainya"(Hendri Subiakto, wawancara data primer, 09 Mei 2018).

Berkaitan dengan aspek penilaian dan pertimbangan dalam memilih dan menetapkan target sasaran pihak dari kemenkominfo dalam konteks mencegah penyebaran ujaran kebencian ini tidak memiliki pertimbangan dan kriteria khusus dalam memilih target sasarannya. Karena pada dasarnya ujaran kebencian ini bisa berdampak pada seluruh masyarakat Indonesia dan mengancam keutuhan dan persatuan bangsa Indonesia. Namun untuk menghadapi fenomena ini pemerintah dalam hal ini kemenkominfo tidak bisa berkerja sendiri, oleh karena itu pemerintah melibatkan atau memberdayakan elemen-elemen masyarakat untuk menjadi mitra pemerintah seperti tokoh-tokoh masyarakat, pemuka-pemuka agama, generasi muda atau biasa disebut generasi millineal.

\section{Teknik Menyusun Pesan}

Kementerian Komunikasi dan Informatika RI memiliki wewenang untuk mengemas, mengelola dan menyebarkan pesan yang ingin disampaikan kepada publik, namun untuk substansi pesan yang akan dibuat kemenkominfo harus melibatkan dan berkeja sama dengan pihak-pihak terkait. kominfo disini hanya memiliki kewenangan untuk mengemas, mengelola dan mendesiminasikan pesan. Sedangkan, substansi pesan yang akan disampaikan kepada masyarakat itu dibuat dengan melibatkan berbagai pihak yang terkait dengan isu atau fenomena yang sedang berkembang di masyarakat. Dalam konteks fenomena penyebaran ujaran kebencian ini kominfo dalam merumuskan dan menyusun pesan dengan melibatkan pihak-pihak terkait seperti K/L yang terkait, tokoh atau pemuka-pemuka agama, tokoh-tokoh masyarakat, anak-anak muda atau generasi muda, kepolisian dan yang lainnya. Seperti yang dituturkan Kepala Subdirektorat 
Pengolahan dan Penyediaan Informasi Ditjen IKP Kominfo: "Seperti yang tadi saya katakan core permasalahan yang kita hadapi saat ini adalah persoalan kecepatan dalam memberikan respon terkait isu yang sedang berkembang di masyrakat khususnya pada isu-isu yang membutuhkan klarifikasi dari pemerintah. oleh karena itu, saat ini IKP memiliki tim satgas yang fungsinya adalah untuk memberikan respon atau klarifikasi secara cepat kepada masyarakat terkait isu-isu yang beredar di masyarakat saat itu. Nah tim satgas ini sebetulnya bekerja tidak melalui proses birokrasi yang tadi saya jelaskan, jadi ketika ada isu yang membutuhkan respon cepat mereka langsung meminta data kepada menteri atau kepala lembaga yang terkait dengan isu dan mereka langsung menyusun pesan-pesan yang akan disebarkan kepada masyrakat, jadi jalurnya mereka meminta klarifikasi data dari instansi terkait dan langsung meminta persetujuan kepala lembaga atau menteri terkait untuk menyebarkan pesan-pesan tersebut" (Nursodik, wawancara data primer, 4 Juni 2018)

Secara teknis penyusunan pesan dalam konteks menghadapi fenomena penyebaran ujaran kebencian. Pemerintah dalam hal ini kominfo lebih menonjolkan sisi atau dampakdampak negatif yang dihasilkan dengan adanya penyebaran ujaran kebencian tersebut, meskipun tidak semua produk pesan yang disampaikan berisikan konten mengenai dampak negatif dari adanya ujaran kebencian namun ada juga konten yang bentuknya adalah literasi,ajakan dan himbauan kepada masyarakat untuk menghindari penyebaran isu sara dan ujaran kebencian serta tidak mudah termakan oleh isu-isu sara yang dilempar oleh pihak-pihak yang tidak bertanggung jawab. Secara teori teknik penyusunan pesan ini menggunakan pendekatan one side-issue yaitu teknik penyusunan pesan yang lebih menekankan atau menonjolkan sisi buruk atau sisi baik dari sesuatu, yang artinya dalam menyusun dan menyampaikan pesan komunikator harus memberi tekanan apakah pada kebaikannya atau sebaliknya pada keburukannya.

Sedangkan dalam teknik penyampaian informasi dan pesan, kemenkominfo menggunakan pendekatan teknik penyampaian informasi dan pesan menggunakan pendekatan informatif, edukatif, persuasif serta repetisi.

\section{Pemilihan Media atau Saluran Komunikasi}

Pemerintah dalam hal ini kemenkominfo menggunakan pendekatan media convergence dalam menyebarkan pesan kepada publik atau masyarakat. Maksud dari media convergence ini adalah kominfo menggunakan berbagai media baik media konvensional maupun media online untuk menyebarkan informasi dan pesan kepada masyarakat atau publik yang tentunya penggunaan dan pemilihan media tersebut disesuaikan dengan target-target sasaran yang telah ditentukan sebelumnya. Hal ini dikatakan oleh Staff Ahli bidang Komunikasi dan Media Massa: "Ya itu tadi kami menggunakan pendekatan media convegence, ada media mainstream seperti media elektronik, media cetak, televisi, radio, film, tatap muka dan lain-lain dikolaborasi dengan media online dan media sosial jadi itu dipadukan lalu isunya apa dan disebarakan melalui media-media tadi. Untuk kriteria medianya sendiri itu kita sesuaikan dengan target sasaran dari pesan yang akan 
disampaikan jadi target sasarannya siapa dan itu nanti disesuaikan dengan media yang akan digunakan. Contohnya untuk menyampaikan pesan mengenai kebijakan pemerintah berarti kan harus menggunakan media yang skalanya nasional sehingga pesannya dapat tersampaikan secara efektif"(Gungun Siswadi, wawancara data primer, 07 Mei 2018).

Dalam konteks menghadapi fenomena penyebaran ujaran kebencian ini media yang digunakan sebagai sarana penyebaran pesan oleh kominfo yaitu menggunakan media online, media sosial dan media konvensional mengadaptasi pendekatan media convergence, karena target sasaran pesan yang akan disampaikan sangat banyak dan luas maka penggunaan berbagai bentuk media untuk menyampaikan pesan menjadi sangat relevan. Pemerintah dalam hal ini kemenkominfo menggunakan berbagai media baik online maupun konvensional yang berskala nasional maupun lokal untuk menyampaikan pesan dan informasi kepada publik, seperti menggunakan media TV nasional, koran nasional, radio nasional, portal berita nasional dan begitu pula dengan media lokal. Selain menggunakan media-media tersebut kominfo juga memanfaatkan media sosial sebagai sarana menyampaikan pesan atau informasi terlebih kepada para generasi muda yang banyak menggunakan media sosial ini sebagai tempat mencari informasi dan berita.

Secara garis besar langkah-langkah strategis yang dilakukan oleh kemenkominfo dalam menghadapi fenomena penyebaran ujaran kebencian ini melalui beberapa tahapan yaitu langkah yang pertama dilakukan adalah dengan membuat program-program pencegahan dalam bentuk literasi dan edukasi kepada masyarakat mengenai fenomena penyebaran isu sara dan ujaran kebencian ini. Bentuk-bentuk pendekatannya ada berbagai macam seperti membuat seminar, sosialisasi, FGD, forum-forum, bimbingan teknis, diskusi publik, penyebaran press release di berbagai media yang bermitra dengan kominfo, menggunakan endorser atau influencer untuk menjangkau generasi muda dan masih banyak yang lainnya. Langkah kedua yang dilakukan yaitu membuat pendampingan berkelanjutan dengan memberdayakan komunitas atau kelompok-kelompok masyarakat. Pemerintah dalam menghadapi fenomena ini tidak bisa bekerja sendiri, pemerintah juga memerlukan mitra-mitra untuk bekerja secara bersama-sama dengan harapan kelompok-kelompok masyarakat ini bisa jadi jembatan atau perpanjangan tangan pemerintah untuk menekan fenomena ujaran kebencian ini agar tidak semakin berkembang dan meluas di masyarakat. Lalu langkah yang ketiga yang dilakukan oleh pemerintah dalam hal ini adalah kemenkominfo yaitu melakukan penegakan hukum, ini merupakan langkah terakhir yang dilakukan oleh pemerintah untuk menghentikan penyebaran konten-konten negatif termasuk ujaran kebencian. Untuk penegakan hukum ini kemenkominfo bekerja sama dengan kepolisian untuk menindak para pelaku atau pihak-pihak yang tidak bertanggung jawab yang menyebarkan konten-konten negatif tersebut.

Terdapat beberapa tantangan dan hambatan, tantangan yang dihadapi oleh pemerintah yaitu sebagian besar masyarakat menganggap bahwa lembaga pemerintah tidak netral 
dan hanya membela rezim pemimpin yang sedang berkuasa saja, sehingga menimbulkan rasa ketidakpercayaan (distrust) dari masyarakat terhadap lembaga pemerintah dan itu menjadikan kesulitan tersendiri bagi pemerintah karena informasi-informasi yang disampaikan menjadi tidak efektif diterima oleh masyrakat karena ada rasa distrust terhadap lembaga pemerintah. Kedua, jumlah orang yang harus diberikan literasi bisa dibilang sangat banyak sehingga itu menyebabkan kurang efektifnya program- Ketiga, tantangan yang dihadapi oleh pemerintah saat ini adalah speed atau kecepatan dalam merespon isu-isu yang berkembang di masyarakat khususnya isu yang menjatuhkan pemerintah dengan data yang tidak valid. program yang dilakukan oleh pemerintah.

\section{Teori Media Literasi}

Rubin (dalam Baran, 2004) menyatakan bahwa media literacy adalah pemahaman terhadap sumber-sumber dan teknologi komunikasi, kode-kode yang digunakan, pesanpesan yang diproduksi, dan seleksi, interpretasi, dan akibat dari pesan-pesan tersebut. Salah satu hal yang dilakukan oleh kemenkominfo dalam pelaksanaan strategi komunikasinya ialah dengan melakukan literasi media kepada masyarakat salah satunya ialah dengan menghimbau dan mendorong masyarakat untuk selalu melakukan proses klarifikasi dan verifikasi terlebih dahulu terhadap berbagai sumber berita dan informasi khususnya yang mengandung konten-konten negatif tujuannya agar masyarakat tidak mudah percaya dan termakan pemberitaaan-pemberitaan tersebut yang disebarkan oleh pihak-pihak yang tidak bertanggung jawab. Faktor yang kedua berdasarkan definisi dari teori media literasi ialah pemahaman dan pengetahuan terhadap kode-kode yang digunakan. Kode-kode yang dimaksud disini lebih kepada indikator-indikator yang menunjukan bahwa informasi atau berita tersebut termasuk ke dalam kelompok konten negatif yang mengandung ujaran kebencian. Pemerintah memiliki suatu alat yang dapat mendeteksi dan mengidentifikasi informasi-informasi yang mengandung konten-konten negatif termasuk ujaran kebencian. Selain itu, kemenkominfo juga mempunyai kriteria atau indikator yang perlu dipahami dan diketahui oleh masyarakat terkait dengan informasi atau berita yang mengandung konten-konten negatif. Harapannya agar masyarakat bisa menilai serta membedakan mana berita atau informasi yang benar dan positif serta mana berita yang mengandung konten-konten negatif. Lalu faktor yang ketiga yaitu pemahaman terhadap pesan-pesan yang di produksi. Pemerintah selama ini mencoba menetralisir isu-isu penyebaran sara dan ujaran kebencian dengan memproduksi pesan-pesan yang tujuannya untuk menghimbau masyarakat, meningkatkan literasi masyarakat, serta mempersuasi masyarakat untuk bijak dalam memanfaatkan media dengan tujuan agar masyarakat tidak mudah terpengaruh oleh pemberitaan dan informasi-informasi yang mengandung konten-konten negatif. Faktor yang keempat yaitu seleksi interpretasi dan memahami akibat dari pesan-pesan yang disampaikan. Pemerintah mendorong masyarakat juga untuk memahami akibat-akibat yang ditimbulkan dari pesan-pesan atau informasi yang disebarkan di media. Dalam konteks penyebaran ujaran kebencian ini masyarakat didorong untuk memahami bagaimana akibat yang ditimbulkan dari penyebaran isu sara dan ujaran kebencian tersebut, setelah memahami akibat yang ditimbulkan dari pesan yang disebarkan itu kan 
mendorong masyarakat untuk lebih berhati-hati dalam menerima informasi dan akan mendorong masyarakat untuk melakukan verifikasi dan klarifikasi terhadap pesanpesan tersebut.

\section{SIMPULAN DAN SARAN}

\section{Simpulan}

Strategi komunikasi yang dilakukan oleh Kominfo dalam menghadapi fenomena ujaran kebencian melalui beberapa tahapan yaitu :

a. Pemilihan komunikator (spoke person)

Dalam menghadapi fenomena ini kemenkominfo menggunakan komunikator atau spoke person yang kompeten untuk memberikan pemahaman dan mempersuasi publik dengan menggunakan komunikator dari pihak-pihak yang terkait dengan fenomena ini seperti pemuka agama, kapolri, menteri hukum dan HAM, serta menteri komunikasi dan informatika.

b. Memilih dan menetapkan target sasaran

Kominfo menargetkan seluruh masyarakat Indonesia termasuk pihak-pihak yang bermitra dengan pemerintah seperti tokoh-tokoh masyarakat, pemuka-pemuka agama, generasi muda atau biasa disebut generasi millenial.

c. Menyusun dan menyampaikan pesan

Secara teknis penyusunan pesan kominfo lebih menonjolkan sisi atau dampakdampak negatif yang dihasilkan dengan adanya penyebaran ujaran kebencian tersebut. Sedangkan dalam teknik penyampaian informasi dan pesan, kemenkominfo menggunakan pendekatan informatif, edukatif, persuasif serta repetisi dengan tujuan untuk memberikan literasi serta melakukan pendampingan kepada masyarakat .

d. Pemilihan media

Media yang dipilih adalah media online dan konvensional yang berskala nasional maupun lokal serta memanfaatkan media sosial sebagai sarana menyampaikan pesan atau informasi terlebih kepada para generasi muda.

Beberapa hambatan serta tantangan yang dihadapi pemerintah dalam hal ini Kominfo :

a. Adanya stigma atau persepsi masyarakat bahwa apapun program dan kebijakan yang dibuat pemerintah itu hanya untuk membela atau hanya berpihak terhadap kepentingan rezim pemimpin yang sedang berkuasa.

b. Pemerintah tidak bisa bergerak sendiri dalam mengimplementasikan strategi komunikasi ini karena jumlah publik yang harus diberikan literasi bisa dikatakan sangat banyak.

c. Kurangnya koordinasi antar lembaga pemerintah (birokratifattitude).

d. Kecepatan pemerintah dalam merespon atau menetralisir isu-isu yang berkembang di masyarakat. 


\section{Saran}

\section{Saran Akademis}

Untuk mendukung data penelitian strategi komunikasi yang dilakukan oleh Kominfo, dengan ini peneliti mengharapkan agar penelitian ini bisa dijadikan sebagai sebuah referensi guna memperdalam penelitian selanjutnya didasarkan dengan data-data yang telah dianalisa dari lapangan.

Peneliti berharap pada penelitian berikutnya untuk dapat lebih mengkaji dan mempelajari bagaimana teknis yang seharusnya dilakukan oleh Kemenkominfo dalam melakukan strategi komunikasi dalam menghadapi fenomena atau permasalahan yang sedang berkembang di masyarakat.

Peneliti berharap kedepannya bisa dilakukan kajian dan penelitian lebih lanjut terkait dengan seberapa besar dampak yang diberikan oleh fenomena penyebaran ujaran kebencian terhadap persatuan bangsa dan dinamika sosial di masyarakat.

\section{Saran Praktis}

Diharapkan pemerintah dalam hal ini Kemenkominfo dapat melakukan pendampingan terhadap mitra diluar pemerintah untuk memastikan bahwa pendampingan serta sosialisasi atau literasi kepada masyarakat betul-betul dijalankan oleh mitra tersebut sehingga program-program pencegahan yang dilakukan dapat menekan penyebaran isu sara dan ujaran kebencian tersebut.

Diharapkan kemenkominfo segera bisa melakukan perbaikan atau merevisi UU ITE yang ada saat ini yang belum lengkap. Harapannya dengan adanya perubahan UU ITE tersebut pihak penegak hukum dalam hal ini kepolisian mempunyai payung hukum serta landasan hukum yang kuat dalam melakukan penindakan terhadap pelaku-pelaku penyebaran.

Pemerintah harus segera melakukan standarisasi profesi humas dalam pemerintah baik di pusat maupun di daerah sehingga mendukung efektifitas dari program yang dilakukan oleh pemerintah.

Mendorong adanya upaya koordinasi atau sinergitas antar humas K/L dengan tenaga humas profesional (THP) sehingga terjadi integrasi dalam hal pembuatan agenda setting untuk menyampaikan informasi kepada masyarakat serta harus ada upaya untuk menekan egois sektoral dalam K/L tersebut.

Diharapkan Kominfo bisa melakukan evaluasi terkait dengan efektifitas strategi komunikasi yang telah dilakukan dengan membuat suatu instrumen survei untuk melihat sudah seberapa efektif program yang dilakukan serta bagaimana respon atau tanggapan masyarakat terhadap strategi komunikasi yang dilakukan oleh kominfo. 


\section{REFERENSI}

Arifin, A. (1994). Strategi Komunikasi. Bandung :CV Amrico

Ayu, Y. (2017, Desember 12). Ujaran Kebencian Picu Generasi Muda Jadi Intoleran dan Diskriminatif https://kominfo.go.id/content/detail/11958/ujaran-kebencianpicu-generasi-muda-jadi-intoleran-dan diskriminatif/0/sorotan_media

Baran, S. J. (2004). Introduction to mass communication : media literacy and culture 3rd edition. Boston. McGraw-Hill

Cangara, H. (2014). PENGANTAR ILMU KOMUNIKASI. Jakarta.PT RajaGrafindo Persada.

Emarketer. (2014). www.emarketer.com,2014

Nur, I. (2017, Agustus 16). SARA, Aduan Konten Negatif Terbanyak yang Diterima Kemenkominfo. Diperoleh dari websitekominfo.go.id/content/detail/10355/sara-aduan-konten-negatif terbanyak-yang-diterima kemenkominfo/0/sorotan_media

Oik, Y. (2014, November 24).Pengguna Internet Indonesia Nomor Enam Dunia. Diperoleh dari website tekno.kompas.com:http://tekno.kompas.com/read/2014/11/24/07430087/P engguna.Internet.Indonesia.Nomor.Enam.Dunia

Sugiyono. (2012). Metode Penelitian Kualitatif. Bandung : Alfabeta. 